\title{
The EU's Education Policy Response to the Covid-19 Pandemic: A Discourse and Content Analysis
}

VAsileios Symeonidis ${ }^{* 1}$, Denis Francesconi² AND Evi Agostini ${ }^{3}$

$\approx$ Following the severe impact of the Covid-19 pandemic on education systems in Europe, the EU has been called upon to provide a concerted response to the crisis in a context where member states provided their own diverse responses. Against this background, the aim of this article is to uncover and critically examine the EU's education policy discourse and promoted narratives since the outbreak of the Covid-19 pandemic, and by doing so evaluate the EU's response-ability for education recovery during the crisis. A conceptual framework has been devised to analyse the responsiveness of an international entity, such as the EU, based on organisational and neo-institutionalist theories. Data were collected through a combination of discourse analysis and computer-assisted content analysis, which was applied to official EU education policy documents published in 2020. The following categories emerged from the analysis process, indicating that the EU perceives education recovery as: "upskilling and reskilling", "digital transformation" and "sustainable development". The findings suggest a substantial continuation between the EU's pre- and post-Covid-19 strategy in the education sector, and even an acceleration in the same direction, revealing a lack of real change in the EU's response, which was focused predominantly on the economic and employability approach to education.

Keywords: Covid-19 pandemic, European Union, education recovery, response-ability, responsiveness

$1{ }^{\star}$ Corresponding Author. Institute of Education Research and Teacher Education, University of Graz, Austria; vasileios.symeonidis@uni-graz.at.

2 Department of Teacher Education, University of Vienna, Austria.

3 Department of Teacher Education and Department of Education, University of Vienna, Austria. 


\section{Odziv izobraževalne politike EU na pandemijo covida-19: analiza diskurza in vsebine}

Vasileios Symeonidis, Denis Francesconi in Evi Agostini

$\propto$ Močen vpliv pandemije covida-19 na izobraževalne sisteme v Evropi je spodbudil Evropsko unijo (EU) k usklajenemu odzivu na krizo v razmerah, v katerih so se države članice različno odzivale. Skladno s tem je cilj članka odkriti in kritično preučiti diskurz izobraževalne politike EU in spodbujene naracije od izbruha pandemije covida-19 ter s tem oceniti zmožnost odzivnosti EU na okrevanje izobraževanja med krizo. Da bi analizirali odzivnost mednarodnega subjekta, kot je EU, smo oblikovali konceptualni okvir, ki temelji na organizacijskih in neoinstitucionalističnih teorijah. Podatki so bili zbrani s kombinacijo analize diskurza in računalniško podprte analize vsebine, ki je bila uporabljena za uradne dokumente o izobraževalni politiki EU, objavljene leta 2020. V procesu analize so se izoblikovale kategorije, ki kažejo, da EU dojema okrevanje izobraževanja kot »nadgradnjo in prekvalifikacijo«, »digitalno preobrazbo« in »trajnostni razvoj«. Ugotovitve kažejo na precejšnje nadaljevanje strategije EU v izobraževalnem sektorju pred obdobjem in po obdobju covida-19 ter celo na pospešitev v isti smeri, kar razkriva pomanjkanje dejanskih sprememb v odzivu EU, ki je bil osredinjen predvsem na gospodarski in zaposljivostni pristop k izobraževanju.

Ključne besede: pandemija covida-19, Evropska unija, okrevanje izobraževanja, zmožnost odzivnosti, odzivnost 


\section{Introduction}

The Covid-19 crisis is a systemic crisis that has created the largest disruption of education systems in history, impacting approximately 1.6 billion learners in more than 190 countries and all continents (United Nations, 2020). While the pandemic is still hitting large parts of the world - it is stated that Covid-19 has sharpened the precarious economic and social situation of millions of people all around the globe (Tcherneva, 2020) - some initial analysis and indications about its effects on education systems have already been proposed. For example, UNESCO (2020) states that the impact of Covid-19 will result in cutting government expenditure on education, having greater consequences for education systems than the great financial crisis of 2007/2008, particularly for low-income countries. Without drastic remedial action, the world could thus face a substantial setback to achieving inclusive and equitable quality education for all by 2030, as promoted by Sustainable Development Goal 4 (United Nations, 2015).

In Europe, the impact of the pandemic has also led to school closures that have brought significant disruptions to education. A report prepared by the European Commission's Joint Research Centre suggests that in a few selected EU countries, including France, Italy and Germany, students will face a non-symmetric learning loss that will have a negative influence on both cognitive and non-cognitive skill acquisition, as well as long-term consequences in addition to the short-term ones (Di Pietro et al., 2020). Despite the Covid-19 crisis being a transnational issue and a common challenge for European societies, country responses were indeed different and revealed the need for more coordinated responses by EU institutions (Iozzo \& Masini, 2020; Schmidt, 2020). According to Grek and Landri (2021), the pandemic provoked the suspension of the mechanisms of European education governance, highlighting the limits of its fabrication, and a return to strong state-centred policies in education. The focus of the EU shifted to the support of member states and the decisions that had to be taken regarding school closures.

At the EU level, important decisions were taken when the Stability and Growth Pact was suspended for the first time in March 2020, and when a longterm EU budget ( $€ 1.8$ trillion) and a recovery plan called Next Generation EU ( $€ 750$ billion) was agreed between EU member states in July 2020. Despite initial hesitation, these initiatives opened a space of possibilities, showing that EU leaders gave priority to the protection of their citizens, suspending the dominant economic regime (Grek \& Landri, 2021). Tied with the new budget and the Next Generation EU plan, the European Commission (EC) updated its education 
strategy for the new European Education Area to be established by 2025 (EC, 2020a), an initiative introduced in 2017 by the Junker Commission. While the Directorate General for Education and Culture's response has been limited to the provision of online materials for learning, the EC recently introduced the European Skills Agenda (EC, 202ob) and the Digital Education Action Plan (EC, 2020c) as measures to improve the resilience of education systems and increase the use of digital technology and learning among member states. Promoting skill acquisition and digital education is not a novelty for the EU education policy agenda (see Panitsides \& Anastasiadou, 2015; Salajan, 2019), but the interest of the EU in these themes has now arguably accelerated due to the pandemic.

The pandemic presents an opportunity for the EU to rethink its priorities on a highly contested issue such as education, much as it has for the economy. It has been argued that EU's education policies promote the neoliberal ideas of "education for the economy" with limited space for the dimension of "social Europe" (Alexiadou et al., 2010, p. 347). Such policies tend to emphasise the contribution of education to building competitive economies and creating skilled workers to produce benefits in the labour market, which are perceived by some scholars as the main factors causing social inequality (Muñoz, 2015; Panitsides \& Anastasiadou, 2015). In this context, the pandemic, which has evidently exposed and exacerbated inequalities in Europe (Di Pietro et al., 2020), could prompt a rethink of the social dimension of European education policy. Since 2017, the EC has endeavoured to make the social dimension of the EU visible through several initiatives that culminated in the development of the European Pillar of Social Rights (European Parliament, Council of the European Union \& European Commission, 2017). Among its 20 principles for a Europe that is "fair, inclusive and full of opportunity" (EC, n.d.), the first principle relates to education, training and lifelong learning and is connected to the European Skills Agenda (EC, 202ob).

Against this background, the aim of the present study is to examine the EU's education policy discourse and promoted narratives since the outbreak of the Covid-19 pandemic. The policy documents produced during this recent period highlight some new priorities that will influence the remaking of the European space of education in the twenty-first century. According to Grek and Landri (2021, p. 397): "these documents represent a new strategy to restore the 'magister of influence' of the EU on the education systems of member states, after the pandemic catastrophe". The objectives of the present study are thus to: (a) identify and analyse the discourses underpinning EU education policy documents published in the context of the Covid-19 pandemic; (b) evaluate the extent to which these discourses reproduce the existing priorities of the EU 
in education or define new ones; and (c) evaluate if and how these discourses contribute to the vision of a new "Social Europe" as mandated by the European Pillar of Social Rights. In doing so, the article helps to understand the principles and values that will be central to post-pandemic education policy at the EU level, adding to the rich body of knowledge that has emerged regarding the impact of Covid-19 on education systems.

\section{Conceptualising the EU's response-ability in education and training}

In order to frame the response-ability of the EU, we should first conceptualise its role in monitoring education policymaking across member states. A unique feature of the $\mathrm{EU}$ is that although the member states remain sovereign and independent states, they have delegated some of their decision-making powers to the shared institutions they have created, so that some decisions of common interest can be made at the EU level. Considering this particular nature of the EU, we draw on organisational and neo-institutional theories and propose a conceptual framework for interpreting the EU's policy discourse for education recovery during the Covid-19 pandemic.

\section{The EU's role and responsibility for education}

At the outset, we should clarify the role and mandate of the EU for national educational issues. In Europe, education has historically been closely connected to nation and state building, and has thus been perceived as an area of legitimate national diversity (Gornitzka, 2006). For almost twenty years after the signing of the Treaty of Rome in 1957, education remained a "taboo" topic (Pépin, 2007, p. 122) and it was not until 1976 that a European Council resolution introduced the voluntary participation of education ministers in the classical procedures of the European Community (Council of the European Communities, 1976). Since then, the European level's responsibility has been focused on mobility, which was strengthened with the establishment of the Erasmus programme in 1987 and the Socrates programme in 1995 (Gornitzka, 2006). With the signing of the Maastricht Treaty in 1992, school education was included in the Community's action programme, but any harmonisation was ruled out and member states remained solely responsible for their education systems:

The Union shall contribute to the development of quality education by encouraging cooperation between Member States and, if necessary, by 
supporting and supplementing their action, while fully respecting the responsibility of the Member States for the content of teaching and the organisation of education systems and their cultural and linguistic diversity. (Treaty on European Union, 1992, Article 126)

The specific article recognises some limited powers of the EU over education, mainly by using the term "quality education" as an area that permits intervention by the EU (Alexiadou, 2007). Until today, nothing in the formal legal parameters has changed in the Treaty when it comes to the principle of subsidiarity and the fact that the EU can only encourage cooperation between member states. In the area of vocational education and training (VET), the situation is different considering that the EU has a stronger legal foundation already from the founding Treaty. In general, education belongs to the "soft" legal competence of the EU, meaning that the EU can propose measures "which are binding on the member states in varying degrees, but which are not compliance-driven in the form of directives, regulations or decisions" (Gaenzle, 2008, p. 4). In contrast to direct or "hard" EU policy, which results in legislation that member states are obliged to implement, soft policy depends on the member states making and implementing proposals, while the EC may have a monitoring role regarding the actual output (Ladrech, 2010).

Since the Lisbon Council in 2000, EU cooperation in education and training has intensified under the umbrella framework of lifelong learning and a new (for the field of education and training) governance instrument for Europeanisation, the Open Method of Coordination (OMC). The OMC has allowed for a degree of EU intervention in national education and other social policy areas that would have been inconceivable before (Hingel, 2001). The aim of the OMC is to spread best practices and lead to convergence towards the main EU goals (European Council, 200o). Among its core characteristics, Alexiadou (2007) refers to the education OMC: (a) as a form of soft law and hence a "light touch" regulatory tool; (b) as a "reflexive" tool of governance, drawing on peer review and policy learning; (c) as involving a range of "actors" in its process of policy learning and exchange, including networks of experts in various fields within education; and (d) as operating on the basis of benchmarks and indicators to stimulate exchange and discussion between member states about reasons for differences in performance (pp. 104-105).

However, the Lisbon agenda "does not acknowledge education as a 'teleological' policy area, an area in itself", but rather as "part of social policy, labour market policy and overall economic policy" (Gornitzka, 2005, p. 17). Similarly, Halász (2013) argues that the European interest in education originates from 
pressures of the wider social policy area, particularly the employment area. In this context, the education OMC seems to contribute more to the goal of "sustainable economic growth" and less to the social cohesion goals of the Lisbon agenda, while following a traditional set of managerial values with strong business orientation informing education indicators (Alexiadou, 2007). Besides, the OMC developed initially as part of economic policy coordination, given impetus through the European Employment Strategy, rather than as an independent policy field (Gornitzka, 2005).

Nevertheless, the wider integration process has intensified and formalised through the OMC, resulting in the emergence of a "European Education Space" and a "European Education Policy" developed within particular historical, economic, political and educational contexts, which allowed education to find its "place" in European policy (Dale, 2009). According to Dale (2009), European education policy is framed not only by the OMC and the respective Directorate General, "but by existing Member State policies and preferences - and, in addition [...] existing conceptions of the nature and capacity of 'education' which, [...], have an existence that is relatively independent of, and pervade, in different ways, all Member State education policies" (p. 32). Based on this distinct idea of a European education policy, the following section presents a conceptual framework for the interpretation of the EU's policy discourse during the Covid-19 pandemic.

\section{Using organisational theory and neo-institutionalism to analyse European responses to the Covid-19 pandemic}

Responsiveness has proven not only to be a crucial individual (e.g., Waldenfels, 2012), but also an organisational (cap)ability (Jesacher-Roessler \& Agostini, 2021). Organisational theory conceptualises responsiveness as an emergent capability that results from interorganisational practices drawing on different structural properties of networks and clusters (Gärtner et al., 2017). Hence, Gärtner and colleagues (2017, p. 16) define responsiveness "as the capability that ensures timely reconfigurations of value systems and that is established among organisational actors from different levels, i.e. organisation, network, and cluster", as well as an "act of sensing [...], seizing opportunities and reconfiguring organisational resources and routines" (Gärtner et al., 2017 , p. 8). Organisational (re-)actions involve attempts to influence changes as they evolve. Thus, organisational theory emphasises the active dimension of responding to change and highlights the central role of interorganisational practices or actions that are geared not only towards reconfiguring operative 
routines, but also towards taking responsibility and gaining legitimacy. In responsive organisation theory, an organisation must learn about the needs and logics of action of internal and external stakeholders.

Ortmann (2010) stresses that the "responding to" of organisations means more than merely reacting, as it involves answering signals and others' concerns while taking responsibility for one's answer. In turn, by responding, organisations shape and influence what is "at stake". In this context, on the one hand, Ortmann (2010) refers to organisations' perceptiveness for mainly unforeseeable but (possibly) strategically relevant discontinuities in the face of unexpected dangers, opportunities or crises. On the other hand, he points to the responsiveness of an organisation when its actions take into account the needs of those affected by those actions. Thus, the organisations' response-ability is mediated by interpretation (meaning) and language, involving the imperatives of both the thing - the situation, the context, the environment - and of communication and cooperation as well as the "claim of the other". In this sense, every response to the claim of the other always brings with it some kind of responsibility.

Summing up, organisations' responsiveness is about being perceptive to stakeholder concerns as well as to the situation and context, and being willing to continually work on different issues, with the aim of influencing change by actively shaping what is "at stake" (Gärtner et al., 2017; Ortmann, 2010). These different modes of influencing "can range from opposing or manipulating to compromising and affirming" (Gärtner et al., 2017, p. 12). What they all have in common is that the course of action and its outcomes need to gain legitimacy within a system of norms, values, beliefs and definitions (Suchman, 1995). Thus, social actors try to accomplish actions that seem to be appropriate or desirable. The fact that organisations can influence which change comes into being creates the need for taking responsibility for these influences and trying to ensure their legitimacy. In the context of our study, it is therefore important to understand that responsiveness is not just developed inside an organisation, but creates value in a network of stakeholders as well as in certain environments and must address different logics of action in order to respond adequately and as requested to crises such as the Covid-19 pandemic. In this sense, the EU as a particular supranational institution has to respond to the norms and regulations of the context as well as to the claims of its stakeholders, e.g., the member states, especially when it comes to soft EU policy actions.

The strategies and modalities that the EU has adopted to "respond" to external and internal shocks like the pandemic were constrained by the short time available due to the emergency situation - which required an immediate 
response - and by the chaos generated by the pandemic - which created disorder, uncertainty and fear at any level, institutional and individual. However, a complex institutional organisation such as the EU has a long history of responses to crisis (Schmidt, 2020) and has accumulated knowledge in this regard. In evaluating responses to the Covid-19 pandemic, Schmidt (2020) argues that EU governance in the Covid-19 crisis may very well result in paradigmatic change toward deeper European integration in some areas, incremental change in others, or even reversal toward dis-integration in yet others. It is therefore important to consider what changed in terms of the policies and how and who was responsible for it during the pandemic and why. To this end, Schmidt (2020) suggests a methodologically pluralist approach, in which different neo-institutionalist analytic frameworks can be useful.

Firstly, historical institutionalism helps to map out the continued regularities, incremental changes and paradigm shifts prior to and during the Covid-19 pandemic (Schmidt, 2020). The focus of historical institutionalism is on institutions, which are understood as "sets of regularized practices with rulelike qualities" and are conceptualised as structures external to political economic actors (Schmidt, 2008a, p. 4). The dominant macro-historical approach tends to emphasise structures and processes much more than the events out of which they are constructed, overlooking the individuals who created those events (Schmidt 2008a). Historical institutional analysis thus helps to describe the kinds of policies put in place in response to some critical junctures, but it lacks the tools to explain them (Schmidt 2020; 2008a, 2008b). Relevant actors need to recognise that something is indeed a critical juncture, and that change is required (Schmidt, 2020). This is why many scholars who employ historical institutionalism to describe "what happened" also add a discursive institutionalist analysis of "who did what why" (Schmidt, 2020). Discursive institutionalism focuses on the substantive content of agents' ideas and/or on the interactive processes that serve to generate those ideas and communicate them to the public (Schmidt, 2008a). As such, discursive institutionalism can help to reveal the reasons and reasoning behind what happened by turning to the agents of change. In the case of EU agents, there is a lot of debate as to who is driving the process of change, with some intergovernmentalists assuming that member state leaders in the Council are in charge and others arguing that the Commission and other EU bodies remain in control (Schmidt, 2020).

In education, as examined above, Europeanisation is neither a linear nor a straightforward process (Alexiadou, 2007), but rather a reciprocal relationship between political negotiations at the domestic and the European level. Domestic actors draw on EU resources and modify power relations, meaning 
that instead of a causal chain going down from the EU to the domestic level, it is more appropriate to consider that there are multiple ways through which EU pressure is refracted, amplified or construed (Radaelli \& Pasquier, 2008). Besides, there are various actors and institutions within member states that do not act in a coordinated way and may respond very differently to European pressures. In order to frame our analysis of EU discourses on Covid-19 and education, we have thus adopted the following lenses by combining organisational theory and neo-institutionalist approaches:

- Historical precedence and existing institutional structures (as in historical institutionalism);

- $\quad$ Organisational norms, rules and dominant ways of working (see, for example, Gärtner et al., 2017; Ortmann, 2010); and

- $\quad \mathrm{New}$ - or old recycled - ideas that are used to effect reforms and frame actual responses (see, for instance, Schmidt 2008a, 2008b on discursive institutionalism)

If we acknowledge that in order to understand the responsiveness of the EU to the Covid-19 pandemic in the particular area of education, research needs to consider both the organisational conditions and the actors' subjective interpretation of these conditions, we bring attention to the concept of discourse. According to Schmidt (2008a,b), discourse is a more versatile and overarching concept than ideas, encompassing not only the substantive content of ideas but also the interactive processes by which ideas are conveyed. It is thus not only "what is said" but also the context of "where, when, how, and why it was said" (Schmidt, 2008b, p. 305).

\section{Method}

In order to analyse the EU's education policy responses to the Covid-19 pandemic, we combined discourse analysis with computer assisted content analysis (Bennett, 2015). According to Bennet (2015), the combination of these two methods is promising, since both are text-focused methods that can meaningfully complement each other, taking advantage of recent developments in information technology and the growth in the availability of searchable and machine-readable digital text in the last two decades. Computer-assisted content analysis is used to track the frequency of particular words across texts, helping us to identify relevant patterns, while discourse analysis allows us to interpret these patterns in the wider social context. The first is usually considered as a quantitative method that can identify texts worthy of close study and 
address whether the findings of individual texts are also evident in populations of texts. The second is perceived as a qualitative method that can contribute to conceptual validity and an in-depth understanding of individual texts. In this study, computer-assisted content analysis was first conducted to identify the most relevant texts and passages, as well as the frequency of words and phrases, which were then interpreted through discourse analysis.

Specifically, a document search was initially conducted in the EURLex official documents database (https://eur-lex.europa.eu/homepage.html), running a search for EU-law documents authored by the European Commission during the year 2020, with "Covid" AND "Education" as title and in-text keywords. The results yielded a set of 19 documents, of which three European Commission Communications and one Proposal for a Council Recommendation were selected as relevant responses of the EU to the impact of the Covid-19 pandemic in education and training (Table 1). The September 2020 Commission Communication is the first major education communication of the new Von der Leyen Commission, which committed to making the European Education Area a reality by 2025. It is also the document that aims to present a "replacement" to the Education and Training 2020 framework for education, promoting the commitments of the new Commission towards the digital and green transitions (von der Leyen, 2019). This Commission launched itself in 2019 as the "Green Commission" with a Digital EU Agenda, which has been very much welcomed by the Parliament and several environmental organisations and Green political parties across Europe.

In this respect, the other two 2020 Communications on the European Skills Agenda and the Digital Education Action Plan build on previous action plans (i.e., the Skills Agenda adopted in 2016 and the Digital Education Action Plan 2018-2020), but they are both tied to the Next Generation EU plan and the effort to recover from the Covid-19 pandemic. While both of these initiatives were already in place before the pandemic, Covid-19 acted as an accelerator and introduced new priorities, such as the attention to the "green recovery", leading to a new strategy of the EU for the education systems of member states after the pandemic (Grek \& Landri, 2021, p. 397). The European Skills Agenda is managed by the Directorate General for Employment, Social Affairs and Inclusion and is aimed at strengthening sustainable competitiveness as stipulated by the European Green Deal and ensuring access to training and lifelong learning for all according to the European Pillar of Social Rights (EC, 202ob). The Digital Education Action Plan is more closely linked to the priorities of the European Education Area, which is presented as an initiative that develops in parallel to the European Skills Agenda, the renewed VET policy and 
the European Research Area. The final document examined, the proposal for a Council Recommendation on VET, also aims to support the European Pillar of Social Rights and take the common vocational training policy one step further since the launch of the Copenhagen process in 2002.

\section{Table 1}

\section{List of selected policy documents for this study}

\begin{tabular}{lc}
\hline Title & Acronym used in text \\
\hline $\begin{array}{l}\text { Communication from the Commission to the European Parliament, the } \\
\text { Council, the European Economic and Social Committee and the Commit- } \\
\text { tee of the Regions on achieving the European Education Area by 2025. }\end{array}$ & EC, 2020a \\
\hline $\begin{array}{l}\text { European Skills Agenda for Sustainable Competitiveness, Social Fairness } \\
\text { and Resilience. }\end{array}$ & EC, 2020b \\
\hline $\begin{array}{l}\text { Digital Education Action Plan 2021-2027. Resetting Education and Train- } \\
\text { ing for the Digital Age. }\end{array}$ & EC, 2020c \\
\hline $\begin{array}{l}\text { Proposal for a Council Recommendation on vocational education and } \\
\text { training (VET) for sustainable competitiveness, social fairness and resil- } \\
\text { ience. }\end{array}$ & EC, 2020d \\
\hline
\end{tabular}

After selecting the specific documents, a single word frequency search was conducted across the dataset with the assistance of the software MAXQDA. The search was limited to the 25 most frequently occurring words containing more than three letters and excluding generic vocabulary with a "stop list" (e.g., and, for, the). A word combinations search was also conducted with two and three words, respectively, applying the same rules as the single word search. The first effort to group patterns into analytical categories resulted in five discursive bundles that were then reduced to three after thirty percent of the material had been analysed following an inductive content analysis of the texts. As shown in Table 2, the three discursive bundles attempt to define the emerging discourses of the EU with regard to education recovery, which is the central notion framing the context of the examined documents. Education recovery thus emerges as discourse of "upskilling and reskilling", "digital transformation" and "sustainable development".

It is not surprising that words such as "skills", "digital" and "green" appear most frequently in the examined policy documents, since these words essentially reflect the headlines of the Commission and Council strategic actions. It is interesting, however, to notice the interplay between the specific words and the ideas of "recovery" and "resilience", which are in effect the post-pandemic objectives of the EU. Each discursive bundle predominantly reveals considerations of "what is said" in relation to education recovery, indicating 
similarities with respect to promoting skills and preparing for the green and digital transitions.

\section{Table 2}

Emerging discourses for this study: Education recovery as...

\begin{tabular}{|c|c|c|c|c|c|}
\hline Category & Vocabulary & Frequency & $\%$ & Rank & Documents \\
\hline \multirow{9}{*}{$\begin{array}{l}\text { Upskilling } \\
\text { and reskilling }\end{array}$} & Skills & 472 & 1.55 & 2 & 4 \\
\hline & Labour market & 60 & .38 & 7 & 4 \\
\hline & Quality assurance & 50 & .32 & 8 & 4 \\
\hline & Lifelong learning & 41 & .26 & 9 & 4 \\
\hline & Skills agenda & 30 & .19 & 12 & 4 \\
\hline & Learning outcomes & 22 & .14 & 19 & 4 \\
\hline & European skills agenda & 10 & .13 & 9 & 4 \\
\hline & National skills strategy & 9 & .12 & 10 & 2 \\
\hline & Labour market relevance & 6 & .08 & 24 & 2 \\
\hline \multirow{10}{*}{$\begin{array}{l}\text { Digital trans- } \\
\text { formation }\end{array}$} & Digital & 474 & 1.55 & 2 & 4 \\
\hline & Digital skills & 82 & .52 & 3 & 4 \\
\hline & Digital education & 72 & .45 & 6 & 4 \\
\hline & Digital transitions & 28 & .18 & 15 & 4 \\
\hline & Digital technologies & 21 & .13 & 21 & 4 \\
\hline & Digital education action & 12 & .16 & 6 & 4 \\
\hline & Advanced digital skills & 11 & .15 & 8 & 3 \\
\hline & Basic digital skills & 9 & .12 & 10 & 3 \\
\hline & Digital Europe programme & 8 & .11 & 16 & 3 \\
\hline & Digital education ecosystem & 6 & .08 & 24 & 2 \\
\hline \multirow{4}{*}{$\begin{array}{l}\text { Sustainable } \\
\text { development }\end{array}$} & Green & 101 & .33 & 19 & 4 \\
\hline & European green deal & 14 & .19 & 3 & 4 \\
\hline & Sustainable competitiveness social & 14 & .19 & 3 & 4 \\
\hline & Sustainable development goals & 8 & .11 & 16 & 3 \\
\hline
\end{tabular}

Based on the content analysis, an interpretative discourse analysis of the policy documents helped to reveal the context and the "where, when, how, and why it was said" (Schmidt, 2008b, p. 305). Although effort is devoted to addressing all contextual aspects, explanation of how and why will be attempted at a more superficial level, because of the difficulty of making causal claims only through documents and without access to social actors' own perspectives. Nevertheless, the discursive approach can offer valuable insights into the nature of the EU's education policy responses and, in combination with organisational 
theory and neo-institutionalism, the ways in which particular concepts become incorporated as appropriate and legitimate in the practice and discourse of policymakers (Alexiadou, 2007).

At this point, we should also acknowledge some limitations of the study. Firstly, the data collected consist of only a few documents. This implicates the examination of four policy documents with direct reference to education and the impact of Covid-19 produced in 2020. It must be said that we are still in the middle of the pandemic and not many official European documents are available on this specific topic. More documents will surely be released in the near future and further empirical analysis will be necessary. Another limitation of this study lies in the restriction to particular methodological and theoretical frameworks, which do not allow for generalisation across the range of similar policy documents from other institutions and comparison with other empirical studies. Finally, we concede that we cannot make claims beyond the results of the relatively small number of documents in this study.

\section{Results}

\section{Education recovery as upskilling and reskilling}

The word "skills" was the third most frequent word appearing in the single word frequency search across all of the EU policy documents examined. When the specific word was combined with another one, the most frequent results were "digital skills" and "skills agenda". It is perhaps not surprising that the EU places such a strong emphasis on skills when it comes to describing the actions for education recovery following the Covid-19 pandemic. The European interest in education originates from pressures of the employment area, and the EU often extends the scope of employment policies to cover aspects belonging to the education sector (Dale, 2009; Halász, 2013; Symeonidis, 2021). From the moment that the Lisbon European Council in 2000 reframed education policies to foster a "knowledge economy", education has been assigned the role of providing a flexible and up-to-date workforce (Panitsides \& Anastasiadou, 2015). The Covid-19 crisis has further exacerbated this approach, whereby education appears to be the means for upskilling and reskilling a competitive workforce that can in turn contribute to Europe's economic recovery and social prosperity. "As Europe sets on its path to recovery, the need to improve and adapt skills becomes an imperative" (EC, 202ob, p. 1). To this end, the Commission has mobilised significant funding schemes to invest in skills, including the Next Generation EU instrument, which are available to member states for financing skills policies. 
Successive EU skills agendas have argued about the need to raise skills levels in Europe to tackle the challenges of increasing productivity and competitiveness, technological change and social inclusion (Hogarth, 2021). Upskilling and reskilling appears as a common priority already from the 2016 New Skills Agenda, which introduced the Upskilling Pathways designed to help adults acquire basic competences in literacy, numeracy and digital skills, as well as a broader set of skills, by working towards an upper secondary qualification (EC, 2016). The specific aim of upskilling and reskilling has also been boosted by the first principle of the European Pillar of Social Rights (European Parliament, Council of the European Union \& European Commission, 2017). In the context of the Covid-19 pandemic, however, this discourse appears more urgent than before because of high unemployment rates and constrained budgets. The latest European Skills Agenda argues with emphasis: "now, more than ever, the EU needs a paradigm-shift on skills" (EC, 202ob, p. 3). Although member states have introduced policies to upskill their workforce and, for example, have attracted skilled workers from outside Europe, the latter can prove challenging in contexts of increasing unemployment (Hogarth, 2021).

Across policy texts, the discourse on skills is included under the umbrella framework of lifelong learning and social fairness, revealing the Commission's effort to find a balance between the ideas of labour market flexibility and social justice, with emphasis traditionally placed on the first rather than the second objective (Panitsides \& Anastasiadou, 2015). Skills and lifelong learning are presented as the drivers of the Union's ambition for a green and digital transition, meaning that Europe should become climate-neutral by 2050 and a global leader in digital innovation. "The EU needs a skills revolution to ensure people can thrive in the green and digital transitions, and to help in the recovery from the coronavirus pandemic" (EC, 202oe, p. 1). In effect, the Commission recognises the deficit of many European countries with regard to facing the challenges of distance education and the emergence of new inequalities, since many people lack digital skills or attend schools with limited or non-existent digital infrastructure (EC, 202ob; 2020c). Thus, ensuring inclusiveness and social fairness when it comes to skill acquisition becomes a central message in all of the examined policy documents and translates into making sure that no one is left behind following the coronavirus crisis. The balancing act between the objectives of the lifelong learning policy and the cohesion policy has been crystallised in the European Skills Agenda as a benchmark: "By 2025, 14 million adults with low qualifications in the EU should participate in learning every year" (EC, 2020b, p. 19).

This so-called "paradigm-shift on skills" would also require building resilience (EC, 2020 b, p. 1), a concept repeated several times to indicate the 
ability of the workforce to learn and adapt in the face of crisis, both personally and professionally. Improving resilience particularly through digital skills is considered a prerequisite to thriving in a technology-driven economy (EC, 2020b; 2020d). Resilience becomes the purpose of VET, along with the notions of sustainable competitiveness and social fairness in the current pandemic era (EC, 2020d). Evidently, the Commission understands VET as the main mechanism to meet the Union's upskilling and reskilling needs, and in this sense "to support the recovery from the COVID-19 pandemic and contribute to building a more sustainable, fair and resilient European Union" (EC, 202od, p. 3). The Commission also considers that supporting European VET as a global reference point in skills development - through, for example, the establishment of Centres of Vocational Excellence - can improve Europe's economic competitiveness at a global scale.

Skill acquisition also appears as a central priority of the European Education Area to be established until 2025. Already before the outbreak of the pandemic, Ministers of Education and Ministers of Finance met for the first time together on 8 November 2019 and agreed that "investing in education, skills and competences is a necessity for all member states and it should be a strategic priority for the EU" (EC, 2020a, p. 4). Skills define the understanding of the Commission regarding quality education, since "mastering of basic skills, including digital competences" and "mastering transversal skills" are the first two objectives that should guide the dimension of quality for developing the European Education Area (EC, 2020a, pp. 5-6). The term quality is consistently employed by the EU as "an entrance to the education sector" (Alexiadou, 2007, p. 106), allowing the Commission to coordinate member states' actions on education, and thus to intervene in an area that is generally considered to be of national concern. By placing skills at the centre of what is considered to be quality education, the aspects of knowledge and attitudes are overlooked, and a plethora of adjectives comes to concretise the various facets of the term, including basic, transversal, digital, technical, entrepreneurial and life skills.

In order to recognise skill acquisition achieved in different contexts, the Commission promotes learning mobility and initiatives for transferring micro-credentials across the EU. In this regard, the Bologna process has been instrumental in opening up higher education to internationalisation and mobility, leading to convergences in terms of the recognition of formal qualifications and the adoption of the learning outcomes approach across member states (Halász, 2017; Symeonidis 2021). In all of the examined documents, the Commission recognises that mobility increases employability and improves people's career prospects. However, we are not talking anymore solely about physical mobility. 
Considering the new realities brought about by the pandemic, "blended mobility" will be integrated into the Erasmus programme by adding a virtual learning component to Erasmus and supporting initiatives such as eTwinning for schools (EC, 2020c, p. 18). In order to enable this kind of mobility, a common European approach to the validation and recognition of qualifications is highlighted as necessary. This is where micro-credentials emerge as a more flexible approach, implying the modularisation of higher education or VET programmes through learning outcomes. However, this flexibility bears the risk of making traditional degrees obsolete, since according to the Commission:

A growing number of adults, with or without a higher education degree, will need to reskill and upskill through more flexible alternatives than a full degree in order to overcome the gap between the learning outcomes of their initial formal qualifications and emerging skills needs in the labour market. (EC, 2020a, p. 16)

In order to avoid such risks, the Commission raises the notion of quality assurance several times and suggests the development of a "European Recognition and Quality Assurance System", as well as further integration of education and training priorities in the European Semester, which is the EU's instrument for annual economic and fiscal coordination of member states (EC, 2020a, $2 \mathrm{O} 2 \mathrm{Ob}, 2 \mathrm{O} 2 \mathrm{Od}$ ). In one text passage, we can see that such monitoring measures appear as a remedy to the crisis: "Third, the enabling framework will foster integration of education and training in the European Semester to reinforce Member States' capacities to recover from the Covid-19 crisis" (EC, 2020a, p. 26). The rise of such quality assurance and evaluation mechanisms at the EU level has previously been criticised as an approach centred on productivity that values the quantitative measurement of predetermined outcomes (Brady \& Bates, 2016; Grek et al., 2009). From a governance perspective, such an approach to quality assurance tends to define certain objects and obscure and hide others for governance purposes (Grek et al., 2009). Linked to the European Semester, the creation of such a quality assurance system will further exacerbate the overarching rationale for data production in terms of both accountability and increased performance. It will also bring education closer to the employment and economic sectors of the EU, where the Union has competences to provide arrangements within which member states must coordinate policy.

Finally, education recovery would arguably not be possible without teachers and trainers, whose competency and professional development is another dimension guiding the European Education Area (EC, 2020a). Teacher professional development is conceptualised within the skill acquisition 
discourse, meaning that professional development should equip teachers with the competences necessary for the twin green and digital transitions, but without defining what kind of competences these should be. The attractiveness of the education profession and its overall social status is connected to the idea of a highly competent profession that supports career progression through the diversification of career opportunities for teachers, trainers and school leaders (EC, 2020a, p. 19). In order to enable the career progression of education professionals, the Commission proposed the development of European guidance for the establishment of national career frameworks during 2021-2022 (EC, 2020a, p. 20). It is a long-standing policy of the Commission to link teacher professional development and career progression with measurable competences (Symeonidis, 2021), an approach interpreted by some researchers as an effort by governments to control teachers by holding them accountable for student outcomes (see Trippestad et al., 2017).

\section{Education recovery as digital transformation}

"Digital skills" emerged as the third most frequent pair of words across all of the examined documents, with the word "digital" coming second to the word "education" in the single word frequency search. The Commission considers the Covid-19 crisis as a learning opportunity for education and training systems in Europe because it accelerated the digital transformation in education, which had already been taking place over recent years (EC, 2020c). "The COVID-19 crisis has brought greater awareness of the need to improve the use of technology in education and training; to adapt pedagogies and develop digital skills" (EC, 2020c, p. 8). According to the Commission, this is not merely a change process, but rather a transformation of education and training systems that takes time and requires investment and the political will to move forward. It is considered a task for the whole of society and should be based on dialogue between the relevant stakeholders, as well as evidence-based monitoring (EC, 2020c). An open public consultation for the Digital Education Action Plan thus took place and several stakeholders expressed their learning experiences during the pandemic (see EC, 2020c)

What becomes clear from the analysis of the policy documents is that the Covid-19 pandemic merely offered the opportunity for advancing the digital agenda in education, since policies about digital education or learning at EU level date back to 1994 (Salajan, 2019). Well before the pandemic, the digitisation of education policy and practice had established itself as a key instrument for the datafication of education, which is the broader process of producing education 
data intended to make systems visible, commensurable and comparable (Grek \& Landri, 2021). However, the intention to enhance datafication is now presented as a way to repair education systems and help them recover (see EC, 2020c).

The urgency of making the digital leap in education is considered "vital for people to achieve their potential without leaving anyone behind" (EC, 2020c, p. 20). Like the category of "upskilling and reskilling", the concepts of "equality" and "inclusiveness" are often repeated in the narrative of the EU to justify policy formulation. Not leaving anyone behind is a central argument for investing in digital education during the Covid-19 era: "Appropriate investment in connectivity, equipment and organisational capacity and skills should ensure that everybody has access to digital education" (EC, 2020c, p. 8). At the core of digital education again lies the discourse around the flexible skills and competences that individuals need in order to face the uncertainties of an increasingly digital economy. This is why basic digital skills are promoted as transferable skills that every citizen should have (EC, 2020c), while a strong focus of the European Education Area is placed on fostering advanced digital skills through specialised education programmes, such as artificial intelligence, cybersecurity and high performance computing (EC, 2020a, p. 12).

It is interesting to note that in some text passages, the Commission envisages placing digital education beyond a mere Science, Technology, Engineering and Mathematics (STEM) approach and towards an ethical perspective. "High quality and inclusive digital education, which respects the protection of personal data and ethics, needs to be a strategic goal of all bodies and agencies active in education and training" (EC, 2020c, p. 8). This is also where the green dimension of digital skills becomes relevant, showcasing the Commission's intention to link the ideas of skill acquisition, digital transformation and sustainable development in any possible occasion. In essence, the European policy space in education becomes a space for developing policy solutions to emerging societal challenges in Europe, such as the green and digital transitions accelerated by the Covid-19 pandemic. Digital education and skills should also contribute to digital literacy and resilience: "Being digitally skilled and acquiring digital literacy can empower people of all ages to be more resilient, improve participation in democratic life and stay safe and secure online" (EC, 2020c, p. 13). Here resilience implies the competence to critically assess information, identify disinformation and manage the overload of information, which are exacerbated in times of crisis.

In addition to equipping learners with digital skills, the purpose of digital education is considered to be the deployment of digital technologies to support teaching and learning processes through, for example, distance and 
blended learning (EC, 2020c). "Digital technology should be harnessed to facilitate the provision of flexible, accessible learning opportunities, including for adult learners and professionals, helping them to re-skill, upskill or change careers" (EC, 2020c, p. 10). Digital technologies can thus enable the flexibility and transfer of qualifications, supporting the European approach to micro-credentials described above. This is one example of how digital technologies can become instrumental in furthering convergences among member states. Another example includes the development of European digital educational content, "which should promote the highest pedagogical and educational quality and respect the diversity and cultural richness of the Member States" (EC, 2020c, p. 10). In order to argue in favour of such convergences, which fall behind the legal competences of the $\mathrm{EU}$, the Commission refers to the potential of digital education to increase the international outreach of the EU. "Digital education initiatives have the potential to help strengthen relations between the partner countries and the EU, but also to strengthen relations within different non-EU regions" (EC, 2020c, p. 19). However, it is also recognised that digital technologies are not fully exploited in member states and that there is a need to increase their innovation performance and competitiveness. The argument that recasts the EU as lagging behind its global competitors is a recurrent theme for justifying the need for a new European approach to digital technologies in education (Salajan, 2019).

Digital transformation also implies a redefined role for teachers, whose digital competences are seen as requiring an update: "Key players, in particular teachers and trainers, should be better equipped and trained to participate more effectively in the digital transformation of education and understand the opportunities this can bring, when used effectively" (EC, 2020c, p. 10). The Covid-19 crisis is again perceived by the Commission as an opportunity for teachers, because they can organise their teaching differently and interact with students on a personalised basis. The Commission suggests that digital competences "should be embedded in all areas of teacher professional development, including initial teacher education" (EC, 2020c, p. 9). Similar to the previous category examined, professional development is linked to teacher evaluation through the development of an online self-assessment tool, a "SELFIE for teachers", and a "European Framework for Digital Competence of Educators" (EC, 2020c, p. 12). 


\section{Education recovery as sustainable development}

Across all of the examined documents, the words "green" and "sustainable" appeared consistently among the most frequently used words. "Green" appears often next to the adjective "digital" to characterise the twin transitions that "hold the key to Europe's future resilience and prosperity" (EC, 2020a, p. 9). In order to achieve the twin transitions, "the Commission recommends prioritising actions to help people acquire knowledge, abilities, values and attitudes needed to live in, develop and support a sustainable and resource-efficient society and economy" (EC, 2020a, p. 18). Similar to the previous categories examined, striving for sustainable development implies that education should foster the acquisition of relevant skills and competences. To this end, the Commission utilises substantial funds connected to the European Green Deal initiative and the Sustainable Development Goals and commits itself to launching a Council Recommendation on education for environmental sustainability in 2021 (EC, 2020a).

Already with previous Council Conclusions (e.g., European Council, 2010), the EU declared its intention to prioritise education for sustainable development, placing it under the lifelong learning perspective and connecting it to the objectives of economic growth, social cohesion and environmental protection. In light of the Covid-19 pandemic, the Commission utilises the urgency of the situation to reiterate its intentions to integrate the green transition and sustainability into school, higher education and VET (EC, 2020a, 2020d). "Greening the VET sector requires first and foremost a greening of the VET programmes, curricula and content, but also managing the VET institutions with due attention paid to environmental footprint" (EC, 2020d, p. 15). In effect, "greening" implies the integration of relevant skills and content in educational programmes, which can be monitored with the development of yet another European competence framework, this time "on education for climate change, environmental issues, clean energy transition and sustainable development, which will spell out the different levels of green competence" (EC, 202ob, p. 13).

It is interesting to note that the Commission links education for sustainability to entrepreneurship and innovation (EC, 2020a, 202ob), promoting them both as economic and social phenomena. In this regard, a central role can be claimed by higher education institutions: "education, research, innovation and service to society, playing a key role in driving the Covid-19 recovery and sustainable development in Europe while helping education, research and the labour market to benefit from talent flows" (EC, 2020a, p. 11). The European Universities Initiative and the Horizon Europe funding scheme are some of 
the EU's instruments employed to promote innovation for sustainable development. Another policy measure that communicates the Commission's social responsibility approach to sustainability is "greener mobility". This implies that programmes such as Erasmus should foster greener and more digital mobility, while physical mobility travel needs to be "carbon-friendly" (EC, 2020a, p. 19).

\section{Discussion and Conclusion}

This article has examined the discourses underpinning the EU's education policy response to the Covid-19 pandemic. Its findings revealed three emerging discourses related to education recovery: "upskilling and reskilling", "digital transformation" and "sustainable development". These discourses will now be discussed in the light of the study's objectives and our conceptual framework.

The Covid-19 pandemic offers a unique opportunity to evaluate the ability of organisations to respond to unforeseen crises. In an attempt to respond to the pandemic crisis, the EU has enacted the specific narrative of "education recovery" taking into account the needs of the member states. This kind of response brings with it a certain responsibility, so that we could argue with Ortmann (2010) that the EU's education response means more than merely reacting to the crisis; it involves answering the concerns of the member states and taking action, mainly through generous funding schemes and supportive initiatives. Considering the limited competence of the EU on education matters, an effort to orient the recovery discourse towards employment and economic priorities becomes evident. This is not surprising considering that the EU's interest in education originates from pressures of the employment policy area (Gornitzka, 2005; Halász, 2013). The EC's focus on employability responds to the need to find the right entry points that would allow consensus building among member states and engage not only Ministers of Education in the process, but also Ministers of Finance, who would essentially provide the funding. Consensus and engagement on these issues is easier, if only because youth unemployment is endemically high in the EU, a process that nonetheless undermines the political and social perception of the education sector. The envisaged integration of education and training in the European Semester further illuminates the trend of shifting educational priorities towards sectors other than education, where the EU has greater competence to monitor and influence change.

The proposed initiatives to deal with the crisis seem to recycle old ideas that are used to propose reforms in education inspired by technological solutionism (Grek \& Landri, 2021). Although the pandemic is widely recognised as 
a window of opportunity for radical changes, it is mainly used as an accelerator to bring forward existing policy agendas characterised by the datafication of education (Brady \& Bates, 2016; Grek et al., 2009), the digitisation of education policy (Grek \& Landri, 2021; Salajan, 2019) and the idea that education should prepare a flexible up-to-date workforce (Panitsides \& Anastasiadou, 2015). Within this context, however, we can also notice an effort to support and promote the social dimension of education. Over the last ten years, we have seen a lot of balancing acts between neoliberal and very much interventionist approaches with high budgets, especially from the European Social Fund in education, as well as several compensatory and corrective social measures. This is also the case with the Covid-19 pandemic, whereby the EU has utilised significant funds, including the Next Generation EU, to help member states recover. The focus on promoting the European Pillar of Social Rights and its first principle on education is also manifested across the examined policy discourses. It is a common objective of all policy texts that recovery should ensure social fairness and inclusiveness, yet always be linked to employment priorities. As such, the idea of investing in people is predominantly conceptualised as a growth and competitiveness factor, and secondarily as a key instrument for social inclusion.

A deep and dramatic crisis such as the Covid-19 pandemic should trigger organisational change, and this includes the necessity to enact not only new actions but also a new axiological framework from which new logics, values and actions derive (Francesconi et al., 2021). Instead of finding or creating new answers to educational issues, old topics have been reinvigorated in the context of Covid-19. For this reason, it seems to be not completely reasonable and perhaps even dangerous to leave untouched the (ethical) logics and framework from which the EU policies derive. The lessons to be learnt from a radical systemic crisis like this one should be themselves radical and systemic. In such hard times, there is no space for superficial or short-term organisational learning. Such learning capacity must be necessarily intended in a broad, deep and holistic sense to include fundamental human and ecological values and a strong axiological framework, which always plays a vital role in an organisation's response-ability. In this way, the European space of education could play a crucial role in relaunching the European political project towards the idea of a new "Social Europe". 


\section{References}

Alexiadou, N. (2007). The Europeanisation of education policy: Researching changing governance and 'New' modes of coordination. Research in Comparative and International Education, 2(2), 102-116. Alexiadou, N., Fink-Hafner, D., \& Lange, B. (2010). Education policy convergence through the open method of coordination: Theoretical reflections and implementation in 'old' and 'new' national contexts. European Educational Research Journal, 9(3), 345-358.

Bennett, A. (2015). Found in translation: Combining discourse analysis with computer assisted content analysis. Millenium. Journal of International Studies, 43(3), 984-997.

Brady, N., \& Bates, A. (2016). The standards paradox: How quality assurance regimes can subvert teaching and learning in higher education. European Educational Research Journal, 15(2), 155-174. https://doi.org/10.1177/1474904115617484

Dale, R. (2009). Contexts, constraints and resources in the development of European education space and European education policy. In R. Dale \& S. Robertson (Eds.), Globalisation and europeanisation in education (pp. 23-43). Symposium Books.

Di Pietro, G., Biagi, F., Costa, P., Karpiński Z., \& Mazza, J. (2020). The likely impact of COVID-19 on education: Reflections based on the existing literature and international datasets. Publications Office of the European Union.

EC. [European Commission]. (2020a). Communication from the Commission to the European Parliament, the Council, the European Economic and Social Committee and the Committee of the Regions on achieving the European Education Area by 2025. COM(2020) 625 final. https://eur-lex. europa.eu/legal-content/EN/TXT/?uri=CELEX:52020DCo625

EC. (2020b). European skills agenda for sustainable competitiveness, social fairness and resilience. $\operatorname{COM(2020)} 274$ final. https://eur-lex.europa.eu/legal-content/EN/ TXT/?uri=CELEX\%3A52020DCo274

EC. (2020c). Digital education action plan 2021-2027. Resetting education and training for the digital age. $\operatorname{COM(2020)} 624$ final. https://eur-lex.europa.eu/legal-content/EN/ TXT/?uri=CELEX\%3A52020DCo624

EC. (2020d). Proposal for a Council recommendation on vocational education and training (VET) for sustainable competitiveness, social fairness and resilience. https://op.europa.eu/en/publication-detail/-/ publication/8e89305c-bc37-11ea-811c-o1aa75ed71a1/language-en EC. (2020e). Factsheet - European skills agenda: Skills for jobs. https://ec.europa.eu/social/BlobServle $\mathrm{t}$ ?docId=22827\&langId=en

EC. (2018). Communication from the Commission to the European Parliament, the Council, the European Economic and Social Committee and the Committee of the Regions on the Digital Education Action Plan. https://eur-lex.europa.eu/legal-content/EN/TXT/?uri=COM\%3A2018\%3A22\%3AFIN EC. (2016). A new skills agenda for Europe: Working together to strengthen human capital, employability and competitiveness. https://eur-lex.europa.eu/legal-content/EN/ TXT/?uri=CELEX\%3A52016DCo381 
European Council. (2010). Council conclusions on education for sustainable development. https://eurlex.europa.eu/legal-content/EN/TXT/?uri=CELEX\%3A52010XG1204\%2801\%29\&qid=1613415023549 European Council. (200o). Lisbon European Council 23 and 24 March 200o. Presidency conclusions. http://www.europarl.europa.eu/summits/lisı_en.htm Francesconi, D., Symeonidis, V., \& Agostini, E. (2021). Fridays For Future as an enactive network. Collective agency for the transition toward sustainable development. Frontiers in Education, 6, 1-10. https://doi.org/10.3389/feduc.2021.636067

Gärtner, C., Duschek, S. Ortmann, G., Schüßler, E., Müller-Seitz, G., \& Hülsbeck, M. (2017).

Emergence of responsiveness across organizations, networks, and clusters from a dynamic capability perspective. JCSM, 9, 7-32. https://doi.org/10.1688/JCSM-2017-01-Gaertner

Gaenzle, S. (2008). Policy-making and new modes of governance in the European neighborhood policy. Jean Monnet/Robert Schuman Paper Series, 8(8). http://aei.pitt.edu/9011/1/ GaenzleCFSPLongedi.pdf

Grek, S., \& Landri, P. (2021). Editorial: Education in Europe and the Covid-19 pandemic. European Educational Research Journal, 20(4), 393-402. https://doi.org/10.1177/14749041211024781

Grek, S., Lawn, M, Lingard, B., Ozga, J., Risto, R., Segerholm, C., \& Hannu, S. (2009). National policy brokering and the construction of the European education space in England, Sweden, Finland and Scotland. Comparative Education 45(1), 5-21.

Gornitzka, A. (2006). The open method of coordination as practice - A watershed in European education policy? http://www.efta.int/media/documents/eea/seminars/omc-140508/gornitzka.pdf Gornitzka, A. (2005). Coordinating policies for a "Europe of knowledge": Emerging practices of the "Open Method of Coordination" in education and research. http://citeseerx.ist.psu.edu/viewdoc/downl oad?doi=10.1.1.505.5639\&rep=rep1\&type $=$ pdf

Halász, G. (2013). European Union: The strive for smart, sustainable and inclusive growth. In Yan Wang (Ed.), Education policy reform trends in G2o members (pp. 267-288). Springer.

Halász, G. (2017). The spread of the learning outcomes approaches across countries, sub-systems and levels: A special focus on teacher education. European Journal of Education, 52(1), 80-91.

Hingel, A. J. (2001). Education policies and European governance - contribution to the interservice groups on European governance. European Journal for Education Law and Policy, 5, 7-16. https://doi. org/10.1023/B:EELP.oooooo6722.94222.78

Hogarth, T. (2021). COVID-19 and the demand for labour and skills in Europe. Early evidence and implications for migration policy. Policy Issues. Migration Policy Institute. https://www. migrationpolicy.org/research/covid-19-labor-skills-europe-migration-policy Iozzo, A., \& Masini, F. (2020). Rethinking the role of the European Stability Mechanism for local communities. European Societies, 23(1), 60-67. https://doi.org/10.1080/14616696.2020.1807040 Jesacher-Roessler, L. A. J., \& Agostini, E. (2021). Responsive leadership within professional learning networks for sustainable professional learning. Professional Development in Education, 1-15. https:// dx.doi.org/10.1080/19415257.2021.1950812 Ladrech, R. (2010). Europeanization and national politics. Palgrave McMillan. 
Muñoz, R. A. (2015). European education policy: A historical and critical approach to understanding the impact of neoliberalism in Europe. Journal for Critical Education Policy Studies 13(1), 19-42.

Ortmann, G. (2010). Organisation, strategie, responsivität: Strategieformation als responsive strukturation. Managementforschung, 20, 1-46.

Panitsides, E. A., \& Anastasiadou, S. (2015). Lifelong learning policy agenda in the European Union: A bi-level analysis. Open Review of Educational Research, 2(1), 128-142.

Pépin, L. (2007). The history of EU cooperation in the field of education and training: How lifelong learning became a strategic objective. European Journal of Education 42(1),121-132.

Radaelli, C. M., \& Pasquier, R. (2008). Conceptual issues. In P. Graziano \& M. P. Vink (Eds.), Europeanization: New research agendas (pp. 35-45). Palgrave McMillan.

Salajan, F. D. (2019). Building a policy space via mainstreaming ICT in European education: The European digital education area (re)visited. European Journal of Education, 54(4), 591-604. https:// doi.org/10.1111/ejed.12362

Schmidt, V. A. (2020). Theorizing institutional change and governance in European responses to the Covid-19 pandemic. Journal of European Integration, 42(8), 1177-1193. https://doi.org/10.1080/07036 337.2020 .1853121

Schmidt, V. A. (2008a). From historical institutionalism to discursive institutionalism:

Explaining change in comparative political economy. Paper prepared for presentation at the American Political Science Association Meetings, Boston Aug 2008. https://www.researchgate. net/publication/228911519_From_Historical_Institutionalism_to_Discursive_Institutionalism_ Explaining_Change_in_Comparative_Political_Economy

Schmidt, V. A. (2008b). Discursive institutionalism: The explanatory power of ideas and discourse. Annual Review of Political Science, 11, 303-326. https://doi.org/10.1146/annurev. polisci.11.060606.135342

Suchmann, M. C. (1995). Managing legitimacy: Strategic and institutional approaches. Academy of Management Review, 20, 571-610.

Symeonidis, V. (2021). Europeanisation in teacher education. A comparative case study of teacher education policies and practices. Routledge.

Tcherneva, P. R. (2020). The case for a job guarantee. John Wiley \& Sons.

Treaty on European Union. (1992). https://eur-lex.europa.eu/legal-content/EN/TXT/

$\mathrm{PDF} /$ ?uri=CELEX:11992M/TXT\&from $=\mathrm{LV}$

Trippestad, T. A., Swennen, A., \& Werler, T. (Eds.) (2017). The struggle for teacher education.

Bloomsbury Publishing Plc.

UNESCO. (2020). Policy Paper 41. COVID-19 is a serious threat to aid to education recovery. https:// unesdoc.unesco.org/ark:/48223/pfoooo373844/PDF/373844eng.pdf.multi United Nations. (2020). Policy brief: Education during Covid-19 and beyond. https://unsdg.un.org/ resources/policy-brief-education-during-covid-19-and-beyond United Nations. (2015). Transforming our world: The 2030 agenda for sustainable development. https:// www.un.org/ga/search/view_doc.asp?symbol=A/RES/70/1\&Lang=E 
von de Leyen, U. (2019). A Union that strives for more. My agenda for Europe. https://ec.europa.eu/ info/sites/default/files/political-guidelines-next-commission_en_o.pdf

Waldenfels, B. (2012). Responsive ethics. In D. Zahavi (Ed.), The Oxford handbook of contemporary phenomenology (pp. 423-441). Oxford University Press. https://doi.org/ 10.1093/ oxfordhb/9780199594900.013.0021

\section{Biographical note}

VASILEIos Symeonidis, $\mathrm{PhD}$, is a postdoctoral researcher at the Institute of Education Research and Teacher Education, University of Graz, Austria. His research interests include teacher education policy and practice, international and comparative education, and experiential dimensions of learning.

Denis Francesconi, PhD, is lecturer at the Department of Teacher Education, University of Vienna, Austria. His research interests include educational theory with a specific focus on embodied education and systems theory, quality of life and sustainable wellbeing.

Evi Agostini, PhD, is an assistant professor in the field of teacher education and school research at the Department of Teacher Education and the Department of Education at the University of Vienna in Austria. Her research interests include (phenomenological) learning and teaching theories, responsive teacher education/school development and aesthetic education. 